\title{
Newly discovered seed dispersal system of Juniperus cedrus questions the pristine nature of the high elevation scrub of El Teide (Tenerife, Canary Islands)
}

\author{
Manuel Nogales* $*$ \\ Beatriz Rumeu* \\ Lea de Nascimento $\dagger$ and \\ José María Fernández-Palacios† \\ *Island Ecology and Evolution Research \\ Group (IPNA-CSIC), Astrofísico \\ Francisco Sánchez no. 3, 38206 La \\ Laguna, Tenerife, Canary Islands, Spain \\ $\dagger$ Island Ecology and Biogeography \\ Group, Instituto Universitario de \\ Enfermedades Tropicales y Salud Pública \\ de Canarias (IUETSPC), University of La \\ Laguna, Astrofísico Francisco Sánchez \\ no. 3, 38206 La Laguna, Tenerife, Canary \\ Islands, Spain \\ \$Corresponding author: \\ mnogales@ipna.csic.es
}

\begin{abstract}
As a working hypothesis, we examined evidence for the former presence of a climacic woodland of Juniperus cedrus above the pine forest in the high elevation area of Tenerife (Canary Islands), which would indicate that the current dominant vegetation (endemic Spartocytisus supranubius scrub) may not be pristine. The main causes of the great regression of this woodland were caused by human activities (timber harvesting, herbivory by goats, and fires). The main support for this hypothesis is the survival of a presumably relict seed dispersal system of the endangered endemic J. cedrus, which relies mainly on the wintering thrush Turdus torquatus. The fact that genetic factors are directly involved in the control of bird migration routes strongly supports the idea that this interaction could be remnant of an older system, probably more widespread in the past. To test this hypothesis, we propose that a paleoecological approach could reconstruct the vegetation dynamics in the Teide National Park (Tenerife) and the past presence of this seed disperser migratory thrush. The analysis of plant microfossils in sediments (e.g., pollen, spores, phytoliths, coprolites, and charcoal) would allow us to evaluate whether the current vegetation is the same as that which naturally existed in the past, and assess the impact of the anthropogenic and natural factors to which it has been subjected during history. The results of these analyses will be useful for future management policies and practices aimed at restoring the pristine landscape and biotic interactions of the Teide National Park. To our knowledge, the case presented in this contribution, based on the high dependence of the seed dispersal of an endemic tree ( . cedrus) on a migratory bird, is the only reported in the context of oceanic islands.
\end{abstract}

\section{High Elevation Environments, Conifers, and Human Settlements in the Macaronesian Islands}

The Macaronesian archipelagos (Azores, Madeira, Salvages, Canaries, and Cape Verde) constitute a biodiversity hotspot. Among plants, a total of 1044 endemic species have been identified (Fernández-Palacios, 2011) and a significant number of them are only distributed in high elevation ecosystems. These archipelagos harbor good examples of these environments on the islands of Pico (Azores; $2351 \mathrm{~m}$ a.s.1.), La Palma (Canaries; $2425 \mathrm{~m}$ a.s.1.), Tenerife (Canaries; $3718 \mathrm{~m}$ a.s.1.), and Fogo (Cape Verde; $2829 \mathrm{~m}$ a.s.1.). In the northern hemisphere, conifers have occupied extensively the high mountain habitats of the temperate mainland regions $(\mathrm{Li}$, 1953). On the oceanic islands of Macaronesia, conifers are absent from Cape Verde and Salvages, but some species have successfully colonized the rest of the archipelagos due to their ability for long-distance dispersal (see Adams, 2011; Rumeu et al., 2011a, 2011b, 2014). For example, Juniperus brevifolia (Cupressaceae) and Taxus baccata (Taxaceae) occur in the Azores; J. maderensis, J. turbinata ssp. canariensis, and T. baccata in Madeira; and Pinus canariensis (Pinaceae), J. cedrus, and J. turbinata ssp. canariensis in the Canary Islands. Four of these six species (J. brevifolia, J. maderensis, J. cedrus, and P. canariensis) are endemics (Rumeu et al., 2014).

Probably, the arrival of humans in these archipelagos rapidly affected the distribution of these conifer species through livestock and plant introduction, burning and clearance to create pasture and fields, and later by severe clear-cut logging (Parsons, 1981; Fernández-Palacios et al., 2004; Petit, 2008). Human colonization took place at different dates, the earliest being in the Canaries by aboriginal Berber populations (2500 yr BP, del Arco et al., 1997), and later by Southern Europeans (1390-1496 in the Canaries, 1419 in Madeira, 1431 in the Azores, and 1460 in Cape Verde). After these first settlements, there has been a successive retreat of all these conifers, to a different extent in each species. Unfortunately, in the case of the Canaries, information about the damage caused to the pristine ecosystems by the indigenous inhabitants is not accurate, since it is based on historical chronicles written by European scholars from the 15 th century onward. These descriptions often idealized the aborigines' lifestyles and do not reflect how much they had already thinned or cleared the forests through intensive free-range goat grazing and the seasonal use of fire and other agricultural practices, even at high elevations (de Nascimento et al., 2009; Morales et al., 2009; Machado and Galván, 2012). However, after the Castilian conquest of the Canaries, the forests suffered a greater recession due to the intense harvesting of timber (Parsons, 1981). While the current $P$. canariensis forest occupies a great extent due to the massive afforestation that occurred after the Spanish civil war (Ceballos and Ortuño, 1976) and J. turbinata remains patchy in distribution, J. cedrus has been on the verge of extinction (Rumeu et al., 2011c). Here, we propose the possible existence of a Juniperus cedrus woodland in the high-elevation area of Tenerife based on historical arguments and our previous ecological studies on this insular juniper (see Rumeu et al., 2009, 2011b). 


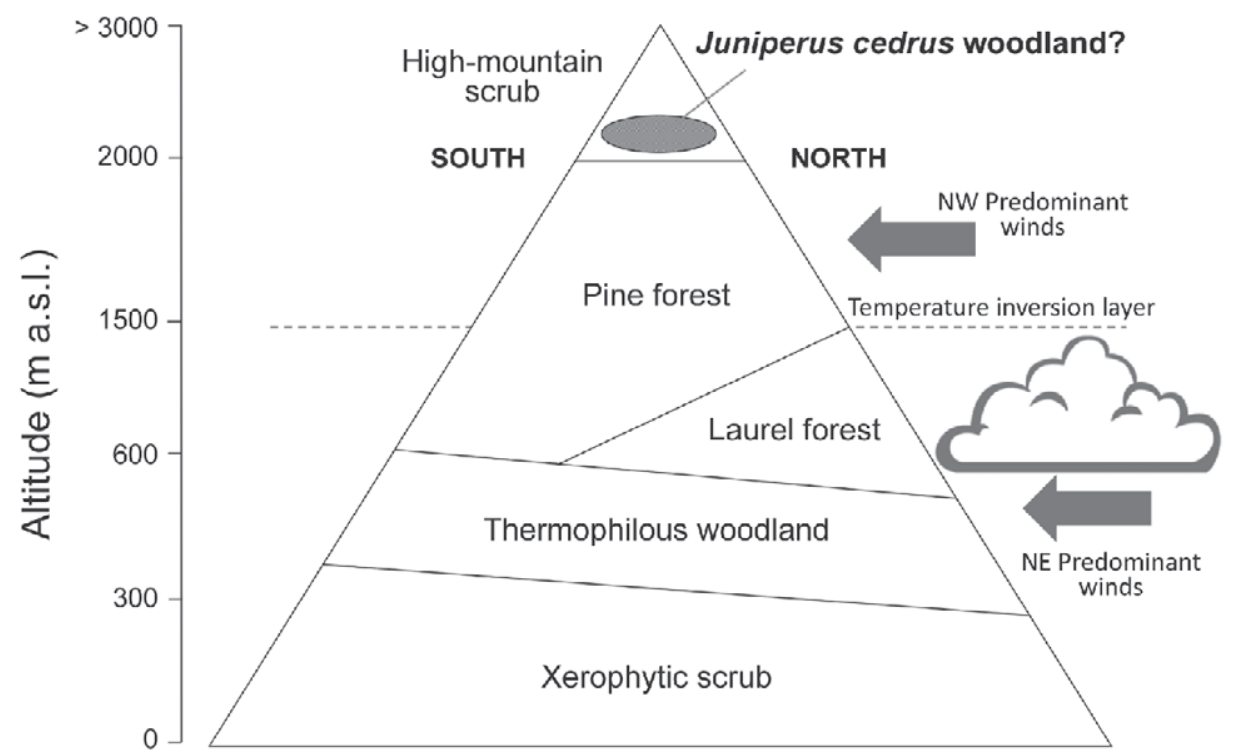

FIGURE 1. Vegetation belts of the Canary Islands (including the proposed Juniperus cedrus woodland), using Tenerife as model.
The climax distribution of $J$. cedrus is still poorly understood and is currently linked mainly to craggy and steep areas of the islands of Gran Canaria, Tenerife, La Gomera, and La Palma (del Arco et al., 2010). Based on historical records (e.g., place names, remains of logged trunks, historical chronicles pointing to the reduction of $J$. cedrus populations due to human pressures), some authors such as Höllermann (1978) and Francisco-Ortega et al. (2009) considered that this endemic species must have occupied a wider distribution range in the past, forming a vegetation belt with its lower elevational optimum situated at the pine forest treeline (Fig. 1). On both Tenerife and La Palma, the surviving individuals are located in steep rocky areas of the high-elevation zone, where the current vegetal landscape is dominated by leguminous species of the genus Spartocytisus, at least in their lower altitudes limiting with the pine forest (see del Arco et al., 2010). In recent decades, these remaining Canarian juniper populations have started to recover slowly, probably aided by the fact that goats were removed from the national park of El Teide after its declaration in 1954. Most of their distribution area currently coincides with the national parks of Tenerife (El Teide) and La Palma (Caldera de Taburiente). Today, at least inside the boundaries of the Teide National Park, but excluding the steep stratovolcano (altitudes $>2700 \mathrm{~m}$ a.s.1.) because of soil instability, J. cedrus is present in a total of 150 squares (square size: $500 \times 500 \mathrm{~m}$ ), which constitute $35 \%$ of the total ( $n=429$ squares) (Fig. 2) (basic data taken from Martín et al., 2005). Although the best formations of this woodland are currently distributed in the surrounding ridges of "Las Cañadas," scattered individuals of this tree are also present in the central basin (excluding the stratovolcano). Furthermore, in this basin some remains of J. cedrus trunks have appeared, enveloped in recent pristine lava flows (E. Carqué, personal communication) (some more than 2000 years old), which indicate that part of the regression of this woodland could be also produced by the recent volcanic eruptions during the past thousands of years (Carracedo et al., 2007). Some years ago, this recovery struck our attention because the only known vector capable of long-distance dispersal of its seeds had been the raven (Corvus corax) (Nogales et al., 1999), which suffered a drastic decrease in numbers (Nogales, 1992; Siverio et al., 2010), having disappeared from the Teide National Park during the early 1990s. The enigma was solved when we recently found a reg- ular migratory population of Turdus torquatus consuming J. cedrus fruits in the Teide National Park during its autumn and wintering stay (Rumeu et al., 2009).

\section{The Seed Dispersal System of J. cedrus}

Seeds from the Canarian juniper are dispersed by two main guilds of dispersers, birds and lizards (Valido, 1999; Rumeu et al., 2011b). In the high mountain zone of Tenerife, J. cedrus female cones and seeds are available all year round, and whereas the birds (specially $T$. torquatus) disperse mainly during autumn and winter, lizards (Gallotia galloti) participate principally in spring and summer (Fig. 3). Despite the notable role of lizards, birds are more important as legitimate and long-distance seed dispersers (see more details in Rumeu et al., 2011b). This ornithochorous "adaptation" in the dispersal of the insular J. cedrus coincides with the dispersal systems of congeners from continental areas, both in Europe (Jordano, 1993; García, 2001) and North America (Livingston, 1972; Holthuijzen and Sharik, 1985). Although the interaction with lizards has been presumably occurring on an evolutionary timescale, their effect on seed germination percentage and rate was negative (Rumeu et al., 2011b). After the extinction of the raven in the range of this juniper population, the wintering $T$. torquatus is now practically the only bird there that has a long-distance dispersal capacity. Although some seeds may be dispersed secondarily when kestrels prey on frugivorous lizards (see Padilla et al., 2012), this complex dispersal is rather limited in the context of the number of seeds dispersed. The regular arrival of $T$. torquatus populations in the Teide National Park is therefore likely to be fundamental to the dynamics of $J$. cedrus, contributing to the persistence of its populations and the maintenance of its genetic diversity. However, this dependence of $J$. cedrus on the wintering T. torquatus for the long-distance seed dispersal implies a great fragility in the system. Although T. torquatus is not a globally threatened species (IUCN, 2013), there has been a decrease in the number of individuals and areas of occurrence within its breeding range in Europe, where it is listed as a species deserving high conservation concern (Sim et al., 2007). At present, the survival of this migrant bird species is a key factor in the conservation of $J$. cedrus, with the management implications this entails. 

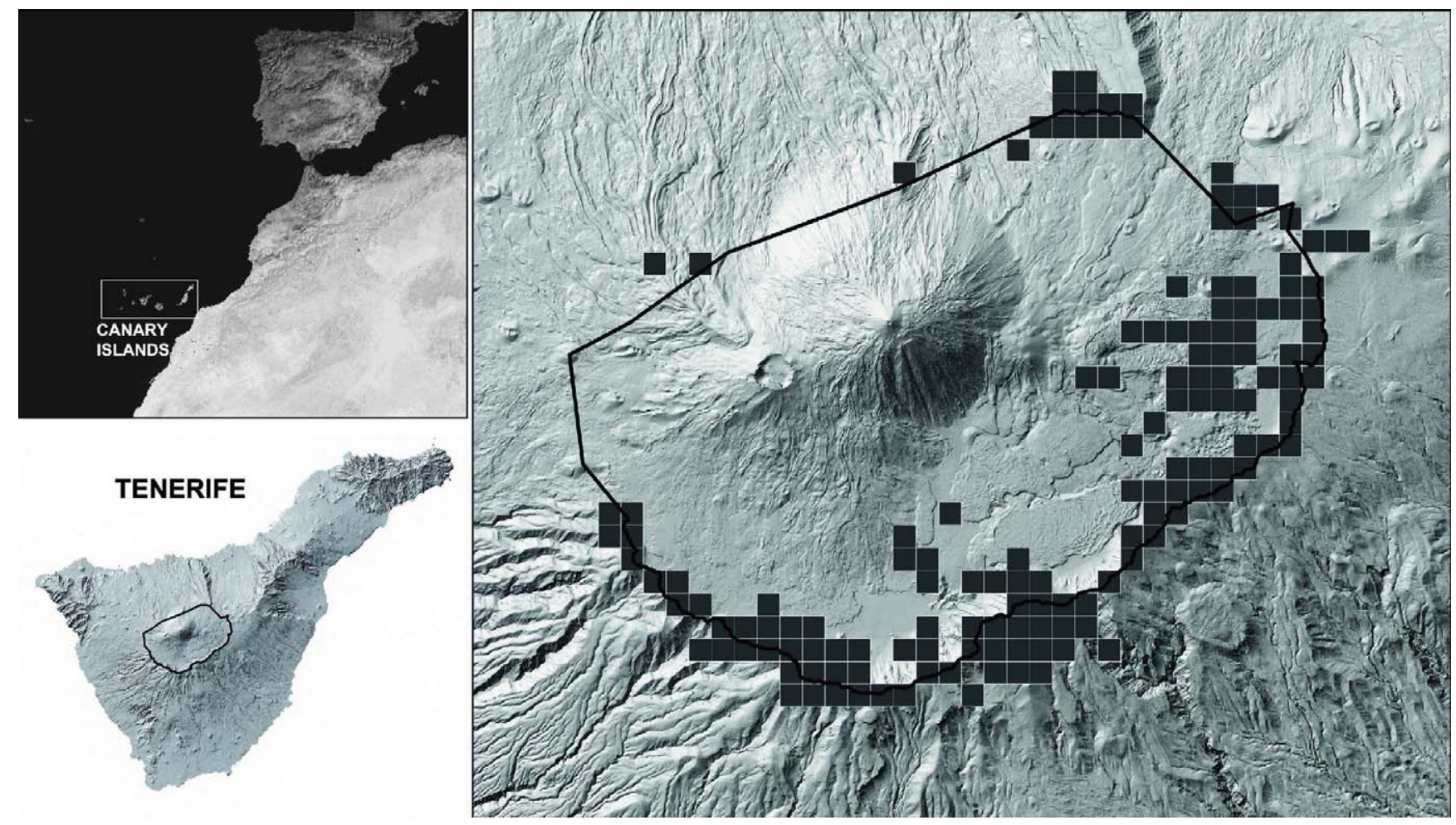

FIGURE 2. The main map shows current distribution of Juniperus cedrus in the Teide National Park. Source: Gobierno de Canarias. Banco de Biodiversidad de Canarias (http//:www.biodiversidadcanarias.es), 27 January 2014. Data precision level '1' (confidence at square level) and distribution in squares $500 \times 500 \mathrm{~m}$. The upper left panel shows the position of the Canary Islands off the northwest coast of Africa, and the lower left panel shows the location of the Teide National Park on the island of Tenerife.

\section{Migration Routes and Bird Fidelity}

Migration is one of the most important events in the context of animal behavior and occurs in a broad array of taxa (Ogonowski and Conway, 2009). Bird movement is a response to changes in food availability, habitat, or weather. The migratory behavior of birds is linked with genetic factors (Berthold, 1991; Berthold and Helbig, 1992; Pulido, 2007), but the relative contribution of genetic versus environmental variables in controlling the tendency to migrate is still poorly understood. Migration has been studied mainly in birds because they carry out long-distance movements and often return to specific breeding and wintering places each year (Ogonowski and Conway, 2009).

The interaction between the Canarian juniper and this migratory thrush $T$. torquatus is presumably not new, and could have existed over a long time. Although T. torquatus was considered as accidental in the Canaries (Cramp, 1998), where Martín and Lorenzo (2001) regarded it as a scarce irregular wintering visitor, we have confirmed its presence during all autumns and winters of the period 2004-2014 (10 wintering seasons) in the Teide National Park, but in relatively small numbers $(<50$ individuals; Rumeu et al., 2009) and showing shy behavior. It has its breeding quarters in Europe, but populations migrate to southern Europe and Africa during autumn and winter. This thrush is also an extremely important seed disperser in the juniper woodlands of the neighboring high Atlas mountains (Morocco, northwest Africa) (Ryall and Briggs, 2006). Given the regular presence of this bird, year by year in the high mountain of Tenerife, all observations seem to indicate that the interaction between $J$. cedrus and the discrete wintering $T$. torquatus has occurred unnoticed for a long time (Rumeu et al., 2009).

\section{Future Study Pathways and Conservation Perspectives}

The hypothesis of a pristine J. cedrus woodland in the high elevation of Tenerife can be addressed now with paleoecological techniques, which permit the reconstruction of past vegetation and climate conditions using fossil organisms (Willis and Birks, 2006). Although pollen analysis is one of the main techniques for studying the response of vegetation to climatic and anthropogenic changes through time (Bennett and Willis, 2001) and has been recently applied in the Canary Islands (de Nascimento et al., 2009; Nogué et al., 2013), in the high elevation zone of Tenerife there are not many suitable deposits for fossil pollen preservation. However, in a preliminary analysis of sediments from this zone, we have found other fossil indicators such as charcoal or phytoliths that resist the arid conditions much better. These type of proxies are usually studied to complement fossil pollen records and are also of great utility in paleoecological reconstruction (Smol et al., 2001). In addition, species belonging to the Cupressaceae family commonly produce phytoliths perfectly differentiable from other families of plants (Piperno, 2006), offering a good opportunity to specifically test the hypothesis raised. Simultaneously, it would also 


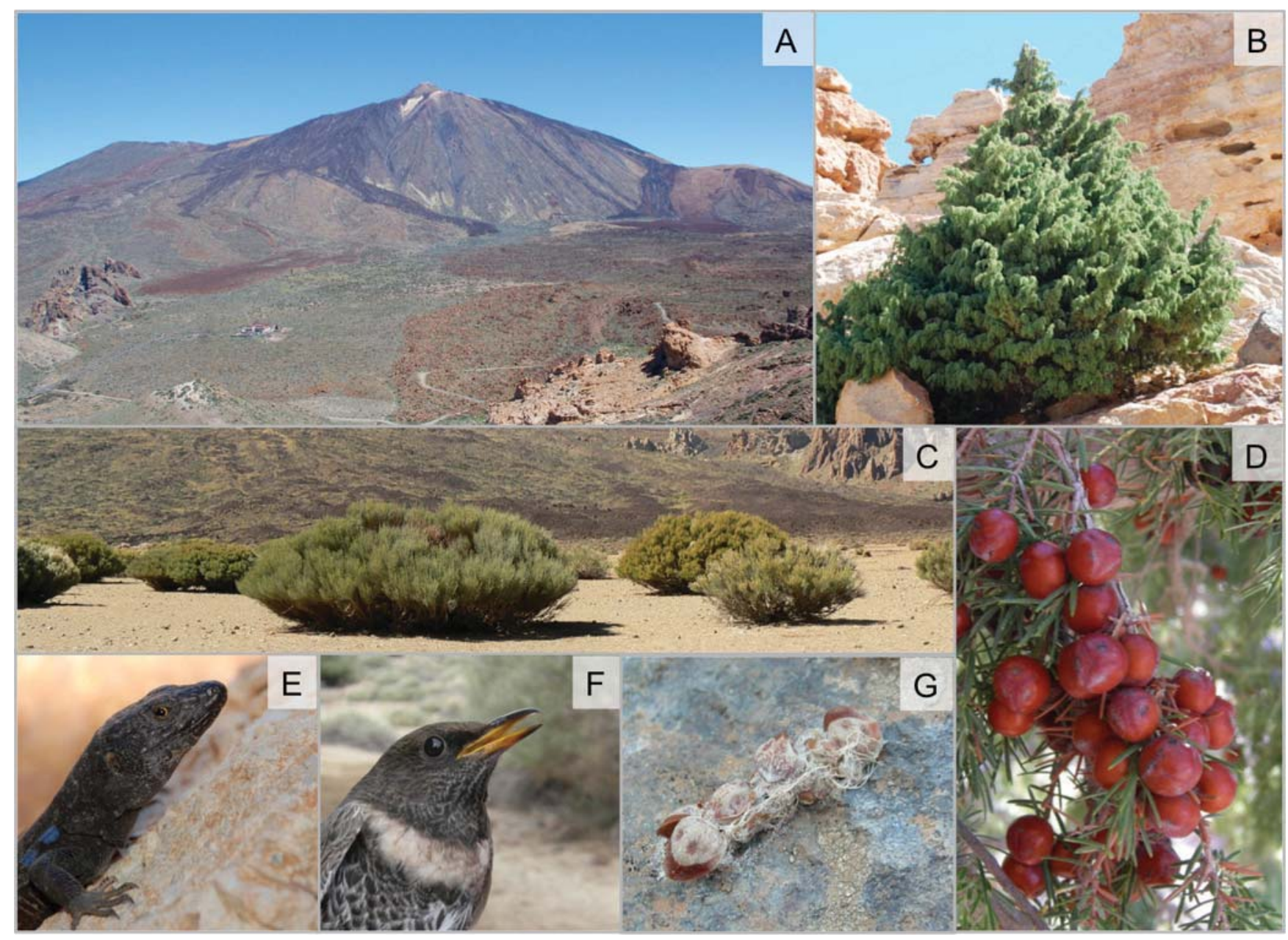

FIGURE 3. The seed dispersal system of the endemic Juniperus cedrus in the Teide National Park. (A) General overview of El Teide volcano, (B) individual of Juniperus cedrus in its current habitat, (C) landscape of the current scrub of Spartocytisus supranubius, (D) J. cedrus mature female cones, (E) the disperser endemic lizard Gallotia galloti, $(\mathrm{F})$ the disperser migratory ring-ouzel Turdus torquatus, and (G) a T. torquatus dropping containing J. cedrus seeds. Photos: A, B, and D-G by B. Rumeu; C by J. Seoane.

be convenient to try to find fossil bones of this thrush preserved in the protection of dry rock overhangs and radiocarbon date their bones to establish the presence of this bird in the past, and therefore its potential as a seed disperser of J. cedrus before the human transformation of Tenerife's island ecosystems. The volcanic caves in the area would be ideal places to search for these bird bone remains.

Paleoecological information and biodiversity management need to be closely linked (Wilmshurst et al., 2013). Especially in highly vulnerable ecosystems like most islands, "natural" vegetation may actually not be in a state of climax as believed by ecologists, but rather be highly altered by human activities and probably the loss of bird dispersers too (Wilmshurst et al., 2013). Thus, a paleoecological approach would be particularly useful on Tenerife for reconstructing the long-term history of J. cedrus on the island, as well as past climates, fire history, and the impact of human settlement and changing herbivory regimes. These factors acquire great importance in highly valuable natural environments such as the Teide National Park. From the conservation management perspective, this knowledge would be decisive in establishing plans to restore the vegetation toward a more pristine environment.

\section{Concluding Remarks}

In the Canaries, despite the drastic decrease in J. cedrus populations as a consequence of its destruction for timber harvest, grazing by goats, and its incapacity to resist fire (Rumeu et al., unpublished data), the populations of T. torquatus have maintained their migratory behavior. As far as we know, the case presented in this contribution, based on the high dependence of the seed dispersal of an endemic tree ( J. cedrus) on a migratory bird is the only reported in the context of oceanic islands. Due to the fact that migratory behavior in birds has a strong genetic component, the mutualistic interaction between $J$. cedrus and T. torquatus probably constitutes nowadays a relict of a more widespread and effective ancient dispersal system. Juniperus cedrus woodland presumably occupied the high elevations of Tenerife and La Palma, at least partially coinciding with the current distribution in steep areas and some locations on recent lava flows in the basin of Las Cañadas. Its lower elevational optimum would have been situated at the pine forest treeline. Its female cones would thus have constituted an important food resource attracting part of the population of these thrushes that migrate to the neighboring Atlas (northwest Africa). There, different Juniperus species coexist and dominate the land- 
scape, providing the basis of the wintering diet of T. torquatus (Ryall and Briggs, 2006). At present, the dominant vegetation of the Teide National Park consists of an extensive scrub of the endemic S. supranubius as the main component together with other leguminous species (e.g., Adenocarpus viscosus). The disappearance of this juniper belt probably permitted the downward redistribution of the leguminous scrublands, more restricted to higher parts in the past. Moreover, J. cedrus is the only native conifer capable of growing in the high-elevation area of the Canaries above the pine woodland timberline. Lastly, we propose that before the human colonization of the Canaries, a climacic formation of a J. cedrus woodland occupied the high mountain of Tenerife and coexisted with these leguminous species, although probably they were not so abundant as today.

\section{Acknowledgments}

Rumeu was funded by a Spanish National Research Council grant (CSIC: JAE-PRE). This study is framed within the projects CGL2010-18759 and PI2007/053 and financed by the Spanish Ministry of Science and Innovation and the Canary Islands Government, respectively; both of which were partially funded by the European Union. The Organismo Autónomo de Parques Nacionales (Canary Islands National Parks Council) also financed this project (051/2010). Eduardo Carqué, Manuel Marrero, Manuel Durbán, Pedro Jordano, and Vicente Soler shared with us important information about the environment of El Teide, and Heriberto López and Helena Morales helped us with the illustration of Figure 2. Several comments and suggestions made by editors and two anonymous referees helped to improve this manuscript.

\section{References Cited}

Adams, R. P., 2011: Junipers of the World: The Genus Juniperus, Third edition. Bloomington: Trafford Publishing.

Bennett, K. D., and Willis, K. J., 2001: Pollen. In Smol, J. P., Birks, H. J. B., and Last, W. M. (eds.): Tracking environmental change using lake sediments. Vol. 3: Terrestrial, Algal, and Siliceous Indicators. Dordrecht, Netherlands: Kluwer Academic Publishers, 5-32.

Berthold, P., 1991: Genetic control of migratory behaviour in birds. Trends in Ecology \& Evolution, 6: 254-257.

Berthold, P., and Helbig, A. J., 1992: The genetics of bird migration: stimulus, timing, and direction. Ibis, 134: 35-40.

Carracedo, J. C., Rodríguez Badiola, E., Guillou, H., Paterne, M., Scaillet, S., Pérez Torado, F. J., Paris, R., Fra-Paleo, U., and Hansen, A., 2007: Eruptive and structural history of Teide volcano and rift zones of Tenerife, Canary Islands. Geological Society of America Bulletin, 119: 1027-1051.

Ceballos, L., and Ortuño, F., 1976: Vegetación y flora forestal de las Canarias occidentales. Santa Cruz de Tenerife, Canary Islands: Excmo. Cabildo Insular de Tenerife.

Cramp, S., 1998: The complete birds of the Western Palearctic. CDROM. Oxford: Oxford University Press.

de Nascimento, L., Willis, K. J., Fernández-Palacios, J. M., Criado, C., and Whittaker, R. J., 2009: The long-term ecology of the lost forests of La Laguna, Tenerife (Canary Islands). Journal of Biogeography, 36: 499-514.

del Arco, M.-J., González-González, R., Garzón-Machado, V., and Pizarro-Hernández, B., 2010: Actual and potential natural vegetation on the Canary Islands and its conservation status. Biodiversity and Conservation, 19: 3089-3140.

del Arco, M. M., Atienza, E., Atoche, P., del Arco, M. C., and Martín, M., 1997: Dataciones absolutas en la prehistoria de Tenerife. In Atoche, P., Millares, A., and Lobo, M. (eds.), Homenaje a Celso
Martín de Guzmán (1946-1994). Las Palmas: Universidad de Las Palmas de Gran Canaria, 65-77.

Fernández-Palacios, J. M., 2011: The islands of Macaronesia. In Serrano, A. R. M., Borges, P. A. V., Boieiro, M., and Oromí, P. (eds.), Terrestrial Arthropods of Macaronesia. Biodiversity, Ecology and Evolution. Lisbon: Sociedade Portuguesa de Entomologia, 1-30.

Fernández-Palacios, J. M., Arévalo, J. R., Delgado, J. D., and Otto, R., 2004: Canarias. Ecología, Medio Ambiente y Desarrollo. La Laguna: Centro de La Cultura Popular de Canarias.

Francisco-Ortega, J., Santos-Guerra, A., and Bacallado, J. J., 2009: Canary Islands, biology. In Gillespie, R. G., and Clague, D. A. (eds.), Encyclopedia of Islands. Berkeley: University of California Press, 127-133.

García, D., 2001: Effects of seed dispersal on Juniperus communis recruitment on a Mediterranean mountain. Journal of Vegetation Science, 12: 839-848.

Höllermann, P. W., 1978: Geological aspects of the upper timberline in Tenerife, Canary Islands. Arctic and Alpine Research, 10: 365-382.

Holthuijzen, A. M. A., and Sharik, T. L., 1985: The avian seed dispersal system of eastern red cedar (Juniperus virginiana). Canadian Journal of Botany, 63: 1508-1515.

IUCN, 2013: IUCN Red List of Threatened Species. Version 2013.2. International Union for Conservation of Nature and Natural Resources, http://www.iucnredlist.org, accessed 28 January 2014.

Jordano, P., 1993: Geographical ecology and variation of plant-seed disperser interactions: southern Spanish junipers and frugivorous thrushes. Vegetatio, 107/108: 85-104.

Li, H.-L., 1953: Present distribution and habitats of the conifers and taxads. Evolution, 7: 245-261.

Livingston, R. B., 1972: Influence of birds, stones and soil on the establishment of Pasture Juniper, Juniperus communis, and Red Cedar, J. virginiana in New England pastures. Ecology, 53: 11411147.

Machado, M. C., and Galván, B., 2012: La vegetación en el valle de Chafarí (Las Cañadas del Teide, Tenerife) antes de la conquista castellana. Cuaternario y Geomorfología, 12: 117-125.

Martín, A., and Lorenzo, J. A., 2001: Aves del archipiélago canario, First edition. La Laguna: Francisco Lemus Editor.

Martín, V. E., Wildpret, W., and Hernández, B., 2005: Avances significativos en la elaboración de la base de datos georreferenciada de flora y vegetación del Parque Nacional del Teide, Tenerife, Islas Canarias mediante un sistema de información geobotánica. Vieraea, 33: 345-358.

Morales, J., Rodríguez, A., Alberto, V., and Machado, C., 2009: The impact of human activities on the natural environment of the Canary Islands (Spain) during the pre-Hispanic stage (3rd-2nd century BC to 15th century AD): an overview. Environmental Archaeology, 14: 27-36.

Nogales, M., 1992: Problemática conservacionista del cuervo (Corvus corax) en Canarias y estado de sus distintas poblaciones. Ecología, 6: $215-223$.

Nogales, M., Hernández, E. C., and Valdés, F., 1999: Seed dispersal by common ravens Corvus corax among island habitats (Canarian Archipelago). Écoscience, 6: 56-61.

Nogué, S., de Nascimento, L., Fernández-Palacios, J. M., Whittaker, J., and Willis, K. J., 2013: The ancient forest of La Gomera, Canary Islands, and their sensitivity to environmental change. Journal of Ecology, 101: 368-377.

Ogonowski, M., and Conway, C., 2009: Migratory decisions in birds: extent of genetic versus environmental control. Oecologia, 161: 199-207.

Padilla, D. P., González-Castro, A., and Nogales, M., 2012: Significance and extent of secondary seed dispersal by predatory birds on oceanic islands: the case of the Canary archipelago. Journal of Ecology, 100: 416-427.

Parsons, J. J., 1981: Human influences on the Pine and Laurel forests of the Canary Islands. Geographical Review, 71: 253-271.

Petit, J., 2008: Macaronesia. In Petit, J., and Prudent, G. (eds.), Climate Change and Biodiversity in the European Union Overseas Entities. Brussels: IUCN, 122-135. 
Piperno, D. R., 2006: Phytoliths. A Comprehensive Guide for Archaeologists and Paleoecologists. Lanham, Maryland: AltaMira Press.

Pulido, F., 2007: The genetics and evolution of avian migration. BioScience, 57: 165-174.

Rumeu, B., Padilla, D. P., and Nogales, M., 2009: The key role of a Ring Ouzel Turdus torquatus wintering population in seed dispersal of the endangered endemic Juniperus cedrus in an insular environment. Acta Ornithologica, 44: 199-204.

Rumeu, B., Caujapé-Castells, J., Blanco-Pastor, J. L., Jaén-Molina, R., Nogales, M., Elias, R. B., and Vargas, P., 2011a: The colonization history of Juniperus brevifolia (Cupressaceae) in the Azores islands. PloS One, 6: e27697, http://dx.doi.org/10.1371/journal. pone. 0027697 .

Rumeu, B., Elias, R. B., Padilla, D. P., Melo, C., and Nogales, M., 2011b: Differential seed dispersal systems of endemic junipers in two oceanic Macaronesian archipelagos: the influence of biogeographic and biological characteristics. Plant Ecology, 212: 911-921.

Rumeu, B., de Sequeira, M., Elliot, M., and Gardner, M., 2011c: Juniperus cedrus. In IUCN, IUCN Red List of Threatened Species. Version 2013.2. International Union for Conservation of Nature and Natural Resources, http://www.iucnredlist.org, accessed 28 January 2014.

Rumeu, B., Afonso, V., Fernández-Palacios, J. M., and Nogales, M., 2014: Diversity, distribution and conservation status of island conifers: A global review. Diversity and Distributions: http://dx.doi. org/10.1111/ddi.12163.
Ryall, C., and Briggs, K., 2006: Some factors affecting foraging and habitat of Ring Ouzels Turdus torquatus wintering in the Atlas Mountains of Morocco. Bulletin of the African Bird Club, 13: 60-74.

Sim, I. M. W., Burfield, I. J., Grant, M. C., Pearce-Higgins, J. W., and Brooke, M. d. L., 2007: The role of habitat composition in determining breeding site occupancy in a declining Ring Ouzel Turdus torquatus population. Ibis, 149: 374-385.

Siverio, M., González, E. I., and Siverio, F., 2010: Population size and status of Common Raven (Corvus corax) on the central-western islands of the Canarian archipelago. Vieraea, 38: 123-132.

Smol, P., Birks, H. J. B., and Last, W. M., 2001: Tracking Environmental Change Using Lake Sediments. Vol. 3: Terrestrial, Algal and Siliceous Indicators. Dordrecht, Netherlands: Kluwer Academic Publishers.

Valido, A., 1999: Ecología de la dispersión de semillas por lagartos endémicos canarios (g. Gallotia, Lacertidae). Ph.D. thesis, Tenerife, Islas Canarias, Universidad de La Laguna.

Willis, K. J., and Birks, H. J. B., 2006: What is natural? The need for a long-term perspective in biodiversity conservation. Science, 314 : 1261-1265.

Wilmshurst, J. M., Moar, N. T., Wood, J. R., Bellingham, P. J., Findlater, A. M., Robinson, J. J., and Stone, C., 2013: Use of pollen and ancient DNA as conservation baselines for offshore islands in New Zealand. Conservation Biology: http://dx.doi.org/10.1111/ cobi.12150. 